\title{
TRAINING METHODS FOR DEVELOPING PROJECT TEAM MEMBERS
}

\author{
Majid G. Al-Nabae ${ }^{1}$ \\ Faculty of Science, Technology, Engineering and Mathematics, \\ International University of Malaya - Wales, Kuala Lumpur, Malaysia. \\ (Email: majidsaad2014@gmail.com) \\ Dania Sammani ${ }^{2}$ \\ Faculty of Science, Technology, Engineering and Mathematics, \\ International University of Malaya - Wales, Kuala Lumpur, Malaysia. \\ (Email: dania01ds@gmail.com)
}

Received date: 09-09-2019

Revised date: 12-09-2019

Accepted date: 26-09-2019

Published date: 15-10-2019

To cite this document: Al-Nabae, M. G., \& Sammani, D. (2019). Training Methods For Developing project Team Members. International Journal of Innovation and Industrial Revolution, 1(1), 01-12.

DOI: $10.35631 /$ IJIREV.11001

\begin{abstract}
There are many factors determining the success or failure of the projects. Skills and competencies play a critical role in project management and shortage of skilled project managers and workers has become worldwide issue and a crucial risk that hindering the projects in achieving their objectives and increase the opportunities of project successful. There are two types of training methods used to provide soft and hard skills for project managers and team members. The aim of this paper is to specify the training methods that have roles in project teamwork training to enhance project performance. This paper uses a literature survey of the content of the research papers in project management training and training methods, to identify what extent training methods are related to project performance. This paper emphases the significance of the training process to enhance the project performance and reveals that on-the-job training, lectures and case study methods are most commonly used in project management training. This paper contributes to increasing awareness of the importance of training methods in project management as a feasible strategy to improve the performance of the projects and amply highlights the importance of skills in project management.
\end{abstract}

Keywords: Skills, Training, Training Methods, Project Management, Project Performance

\section{Introduction}

Projects play a vital role in current enterprises as the project management skills are so critical in projects implementation and managing projects without good skills is a false business(Ramazani \& Jergeas, 2015). As a main participant, the skills and competences of the project manager are the key factors to succeed(Erbas, 2016). In the same context, the poor 
performance team led to project failure(Kum, Cowden, \& Karodia, 2014). It is broadly agreed that skills and knowledge are very important and the performance of the skilled project managers is higher than unskilled ones especially in concluding projects successfully(Telukunta, Kota, Potti, Shashank, \& Reddy, 2014). The intensity of using project management methodology creates a rapid increasing demand to improve the attitudes, skills and knowledge of the project managers(Jałocha, Krane, Ekambaram, \& Prawelska-Skrzypek, 2014). And understanding the project managers' abilities will help organizations to consider training impacts more seriously in the future(Ramazani \& Jergeas, 2015).

Training as an administrative process aims to develop the performance of staff and teams(Vinesh, 2014). Generally, companies have increasingly been applying projects and programs to accomplish their strategic plan and objectives(Bredillet, Tywoniak, \& Dwivedula, 2014). Therefore, training as a development strategy is required to acquire techniques, knowledge, and skills(Vinesh, 2014). A skilled project team is essential and planned training for team members at elementary levels to master basic working capacities and skills is crucial to enhance the business growth and achieve employees' professional success(Zhang, Yu, \& Lv, 2017). Nowadays, and due to the complex work environment, a gap emerges between theoretical knowledge which is offered by education providers and the realistic demand to manage projects. Effective project management training emphasizes flexibility structure, and creativity(Ramazani \& Jergeas, 2015).Training participants, training providers and managers highly value the execution of new knowledge, attitudes, skills which are developed by training(Erina, Ozolina-Ozola, \& Gaile-Sarkane, 2015). Training, in general, includes all activities planned to improve the skills of the team members of a project(PMI, 2017). In training world, two main training methods, through which trainees can be cross trained, are adopted. They are the off-the-job training and on-the-job training(Falola, Osibanjo, \& Ojo, 2014; S.Vasanthi \& Basariya, 2019). Off-the-job training, takes place out of the workplace, which helps eliminating stress, frustration and bustle of day-to-day job, whereas , on-the-job training, is conducted within the work environment, the trainees perform a job while training and learning(S.Vasanthi \& Basariya, 2019).

\section{Research Methodology}

This paper reviews the content of the papers in project management training and training methods, to identify what extent project training methods are relevant to project management skills development. This paper intent is to focus on the academic journals in the project management field, and training methods and the first stage began with data collection through a literature review and focused on discussing the papers outcomes, emphasizing the significance role of training methods in the literature.

\section{Literature Review}

\section{Skills Training and Project Performance}

Training strategy includes various activities created to improve the skills and competencies of the project team members(Project Management Institute, 2017). Companies usually become more sensitive and conscious because they need to provide some proofs about the positive impact of training on project performance in order to justify the training costs(Kagona, Shukla, \& Oduor, 2015). and the project schedule determine when and how to provide training to the members of project team and develop the skills required at different phases(Project Management Institute, 2017). 
Soft skills play a central role in determining project performance or the project success and that soft skills required for the success of institutions(Ibrahim, Boerhannoeddin, \& Bakare, 2017). The design of training methods can have an significant effect on the trainees' skills acquisition, the growth of integration of technology in existing systems, in addition to the newer systems is higher than that of development in training methods(Nazir, Øvergård, \& Yang, 2015). Generally, each project executed in organizations needs a team with certain abilities, skills and competences. Therefore, the project manager has to form a team of expert engineers and scientists before carrying out the project for the project success(Zhang et al., 2017).

Project managers should combine skills and technical knowledge that lead to effective management for the project and to coordinate and communicate of projects' stakeholders(Dziekoński, 2017). So, knowledge and skills are important in project management(Khamaksorn, 2016) . By using multi-skill training, the firm can broaden employees' insights and enhance their flexibility with innovative skills and minds(Isabel, Aragón, Jiménez, \& Valle, 2014). If there is a lack of experience in the managers of projects ,we can fill the gap by training of a project manager in both soft skills and hard skills(Jena \& Satpathy, 2017). Hard skills are not enough in today's increasingly complicated and competitive global marketplace. Organizations are seeking added skills in leadership and business intelligence(Project Management Institute, 2017).

The role of project manager is critical in project management technique and he is the responsible person for project progress, not only for time, cost and quality management, but also integration, , human resource, communication, risk, scope and procurement management(Radujkovi \& Sjekavica, 2017).

The project management technique provides an essential, but imperfect tool for managing new product development(Pons, 2016). Project managers need to acquire leadership competencies and skills such as communication and other skills that help to enhance team performance(Ramazani \& Jergeas, 2015). The project management skills can be divided into hard skills and soft skills, hard skills refer to items like project management tools and governance. Soft skills refer to topics like leadership and teamwork, and interpersonal skills(Savelsbergh, Havermans, \& Storm, 2016). In the same context, Project management institute studies classify skills into two types soft and hard skills(Takey \& Carvalho, 2015). Soft skills consist of leadership and business management skills and hard skills are technical skills(Project Management Institute, 2017). The existence of soft skills and hard skills in project management should be concomitant, balanced, and parallel(Manullang, 2017). And the evaluation where to focus more hard or soft skills is the more challenge in project management(Achaliya \& Agarwal, 2016). Some researchers suggest that the productivity of hard skills stems from their combination with soft skills(Balcar, 2016).

\section{Training Methods}

The training methods can be classified into two groups of training which are off the Job training and on the Job training(S.Vasanthi \& Basariya, 2019). On- the -job training includes many methods such as : coaching, mentoring, understudy method, job instruction technology , apprenticeship technique, and job rotation, whereas Off -the- job training is classified into many method such as : lectures, case study, business games, simulation exercises, audio- visual method, role play, vestibule training, behavioural modelling, discussion method, conference, Seminars, and workshops (Falola et al., 2014;Oseghale, Malik, Nyuur, Pereira, \& Ellis, 2018; S.Vasanthi \& Basariya, 2019). 


\section{On the Job Training}

On-the-job training is a technique of training that perform at the workplace to perform a determined job, during the performance of a job and within the work environment(Matsuo, 2014; S.Vasanthi \& Basariya, 2019). On-the-job training has a crucial role in building up the abilities and competencies of the team members(Konings \& Vanormelingen, 2014), and hence outstanding OJT trainers executes four types of training skills: monitoring their progress, extending the objectives of the trainees', providing them positive feedback, and encouraging reflection on the outcomes(Matsuo, 2014).

These methods are well-known as most effective and they use as a tool to provide skills for project manager to perform their project activities and tasks(Sabir, Akhtar, Bukhari, Nasir, \& Ahmed, 2014). On-the-job training methods are essential methods to develop the competencies and skills of managers, about 70 per cent of training and learning occurs through on-the-job training methods(Matsuo, 2014).

It is better for project teams to learn through on the job training to gain competencies and skills. The actual working environment provide good climate for training employees to be trained in a short period(Galport \& Azzam, 2017; Takey \& Carvalho, 2015).for this reason ,The huge majority of project manager skills training is on the job as responses to problems they face in their daily working(Sharma, 2014). Project managers learn from assignments that are challenging and very difficult and training which take place on workplace environment(Kum et al., 2014). And as the team members are train at the actual working environments, they use the actual equipment and tools that will use in future to be confident when they are working in their jobs(S.Vasanthi \& Basariya, 2019).

In addition ,on-the job training methods use to provide skills and learn how to work in project environments and through the project tasks(Gemünden, Lehner, \& Kock, 2018). And they help employees to gain knowledge and skills of their jobs in a prefect way, it is better for organizations to provide their staff on the job training to learn in a practical way and help to transfer knowledge and skills from one project to other projects inside the organization(Gemünden et al., 2018; Omolo, 2015).

On- the -job training can classify into many methods, for example mentoring, coaching, job instruction technology, job rotation , understudy, and apprenticeship(Falola et al., 2014; Oseghale, Malik, Nyuur, Pereira, \& Ellis, 2018; S.Vasanthi \& Basariya, 2019).

- Coaching: Coaching is the process of supporting a team or a person to improve styles of learning, ways of thinking, and how to face the challenges of project management(Thompson \& Cox, 2017). It is an effective training method to the development of project managers(Savelsbergh et al., 2016). Coaching technique enhances the improvement of leadership skills and competencies(Smits, Bowden, Falconer, \& Strasser, 2014). The organization's project managers utilize coaching as a means to deal with daily problems , to develop confidence and solid self-efficacy(Berg \& Karlsen, 2016).

- Mentoring: it is a personal interaction and one-to-one communication between the expert employees and the new employees, it focuses on the improvement of personal attitude(S.Vasanthi \& Basariya, 2019). Hence, a good mentoring process is critical to achieve the projects successfully(Nakanjako et al., 2014). In project management , mentoring is an active method to train novice employees and to solve problems and conflicting in project workplace(Fagerholm, Guinea, Münch, \& Borenstein, 2014). Mentoring technique presents a alot of advantages for companies, a positive impact on 
influence on trainee performance and is cost effective, and it does not need significant resources and the critical benefit is a rapidly introduction of new employees(Brien \& Hamburg, 2014).

- Job Rotation: This method is a systematic actions of shifting staffs from job to job in the same project or from project to project within a firm, as a way to utilize the human resources(Santos, Fabio, Teresa, \& De, 2017). It affects positively the employees' job performances, favorably and significantly in businesses and reduces boredom and exhaustion due to repetition, job simplification, and specialization(Oparanma \& Nwaeke, 2015; Santos et al., 2017). This method focuses on shifting employees from job to another job, or from a country to another country to develop their abilities on different jobs and responsibilities(Rodriguez \& Walters, 2017).

- Job Instructional Technique (JIT): The core of this method is to expand their experiences in difference tasks by shifting the staff from one department to another(Abomeh \& Peace, 2015).This method helps to recognize when the trainee has learned, to deliver step-by-step instruction and to be due diligent in different organizational environments(Indira, 2017).

- Apprenticeship: It is a system of training to guide the novice staff in a project from beginning to proficiency under the supervision of skilled experts(Downey, Dalidowicz, \& Mason, 2015).It is a formalized method of training program that involved both formalized on-the-job training method and knowledge under supervision(Corseuil, Foguel, \& Gonzaga, 2019). Apprenticeship training methods have designed to develop skills and competencies that is connected to the innovations limit to enhances innovations in the business organizations(Rupietta \& Backes-Gellner, 2018). This technique aims to train project teams to achieve projects as planned by depending on skills of interpersonal , communication, and institutional skills(Vaughan, 2017).

- Understudy: In this method an expert gives training to a subordinate to develop his skills and competencies to take the full responsibilities and duties(Raheja, 2015). In the same context, The subordinate should participate in solving day-to-day conflicts and problems therefore he takes on-the-job practices and train through day-to-day observation and experience(S.Vasanthi \& Basariya, 2019). Understudy technique use to provide technical ,soft and problem solving skills(Rui, Ismail, \& Hussaini, 2015).

\section{Off-the-Job Training}

Off-the-job are types of training techniques organized apart from the workplace; however, training tools are provided. In this type of training a full focus on knowledge learning rather than skills performing, and the participants can also discuss and express your views freely(Raheja, 2015). There are many types of the off-the-job training methods like: lectures and conferences, games-based training, vestibule training, simulation exercises, sensitivity training(Akter, 2016; Indira, 2017; Raheja, 2015; S.Vasanthi \& Basariya, 2019).

- Lectures: It is the well-known method of training and it is used for much of project management knowledge, terms and requirements which is delivered through lecture technique, regardless of its usefulness and effectiveness(Ramazani \& Jergeas, 2015). The instructor of this technique distributes training material to trainees, by means of oral instruction(Martin, Kolomitro, \& Lam, 2014). 
- Simulation Exercises: It is a tool for training by experimentation via artificial or simulated workplaces exactly similar to the actual cases, Case study, management games, in-basket training, and role playing are used for transmission of training as the main simulation techniques(Jeong \& Bozkurt, 2014; Raheja, 2015). The simulation training exercises are precious training instruments, which both project managers and team can use and these games uses in project management training(Jeong \& Bozkurt, 2014). In project management, project managers, engineers and pre-service workers play the simulation games to experience engagement and intrinsic motivation, in addition to think strategically about the options available, and hence focuses on all the topics that might go wrong in their work(Misfeldt, 2015).

- Games-Based Training: This technique is a competitive training method, which is commonly a motivating characteristic for the most of trainees(Martin et al., 2014). The main goal from these games is to supply unskilled project managers and teams with the opportunity to face professional hardship and obstacles, in a joy and motivating manner, leading the trainees to think, act and make their own decisions(Eduardo et al., 2015). the utilization of games-based technique will enhance training in project management by providing actual cases into the learning and training(Calderón \& Ruiz, 2014; Telukunta et al., 2014).

- Case Study: This method offers investigative style and it defined as immersive exploration technique of realities(Minniti, Melo Jr, Oliveira, \& Salles, 2017). It always uses in project management training to present descriptive situations to reinforce team competencies and skills, to improve decision making skill, communication and interpersonal skills, and strengthened analytical skill, it occupies a very important rank among the other methods and techniques(Erbas, 2016). This technique provides the trainees a chance to improve abilities and competencies by presenting problems, without solutions, for them to overcome and solve, or with suggested solutions, as an exemplar of how to solve them(Martin et al., 2014).

- Role Playing: In this method the participants perform the role of an affected person by some elements and review the effects of these elements on human life and/or the impacts of human activities on the reality from the perspective of that affected person(Indira, 2017). The role play technique encourage trainees to see the outside world from different points of views, and estimate how they would behave if in a specific role(Thomas et al., 2018).

- In-Basket Training: In-baskets training method is high-fidelity simulations performed to expect performance in different jobs such as managerial occupations, and law enforcement(Whetzel, Rotenberry, \& Mcdaniel, 2014). It provides trainees with knowledge and demands, or written text which could be handled by directors, project managers, or reporting officers(Miri, Mansor, Chasempour, \& Anvari, 2014).

- Sensitivity Training: This method concentrates on how to make trainees appreciate themselves and others wisely, It is achieved by improving social sensitivity and behavioral flexibility in them(Miri et al., 2014). Sensitivity training motivates project managers and teams to be involved in perspective-taking so that it is easier for them to understand and accept other points of view to reach a mutual understanding. Sensitivity training also helps team members to fit their skills for respecting others in work environment(Chaubey \& Subramanian, 2014). 
- Vestibule Training: Vestibule Training is a type of training techniques and it is defined as a near-the-job training method. In this method, the team members practice their skills with machineries, materials, or instrument that they use at their work environment(Abomeh \& Peace, 2015). Mostly this training technique uses in project to train team members, technical staff, and administrative staff who work with equipment's and tools(Singh \& Jain, 2017).

\section{Discussion and Conclusion}

\section{Training Method In Project Management}

This paper focuses on the training methods which use in project management training and their impacts on project performance. The literature analysis revealed that skills of project manager can classify into two types soft and hard skills, and to acquire these skills there are two tyes of training menthods : on- job and off -the- job training methods which are profitable methods to motivate and insipre the project team members and then enhance the performance of projects. the training and development methods have been classified into two kinds on-the-job which involves mentoring, coaching, job instruction technology, understudy method, job rotation ,and apprenticeship technique) and Off-the-job which includes simulation exercises, lectures , case study, business games, audio- visual method, vestibule training, role play, behavioural modelling, discussion method, conference(Falola et al., 2014; S.Vasanthi \& Basariya, 2019). And most of project management skills and knowledge learning gives by using on the job training techniques and emphasizes the importance of on-the -job training methodology(Kum et al., 2014; Matsuo, 2014; Tamm, 2018).

\section{On-The-Job Training Methods and Project Performance}

Savelsbergh et al., (2016); \&Thompson \& Cox,( 2017)come to conclusion that coaching is treated as an suitable technique for competencies and skills development of project managers. And some researchers like(Brien \& Hamburg, 2014; Fagerholm et al., 2014)stated that mentoring is an approprite method to train junior staff and to face challenges resulting from weak system documentation in project management . Moreover, mentoring and coaching methods can be effective tools to develop leadership in project management according to(Smits et al., 2014).

Oparanma \& Nwaeke, (2015); Rodriguez \& Walters,( 2017);\& Santos et al., (2017) presented job rotation method as a good method uses in project management training that allows project manager to shift one expert staff from the source project to another project (the target project) within the firm to enhance the performance. In addition,(Indira, 2017)discussed Job Instructional method and described it as a valuable tool for all trainees, it helps trainers to provide gradual and step-by-step instructions, to realize when the trainee has learned and to be due diligent in different work environments.

Raheja, (2015); Rupietta \& Backes-Gellner,(2018);\&Vaughan, (2017)suggest that apprenticeship technique is a method of training that a new generation of practitioners of a skill will be able to complete projects on time and it is in vogue method today in business, technical jobs, and crafts. In addition, the understudy assignments perform to the technical skills learning and Interpersonal. However, skills such as problem-solving strategies are acquired more effectively through training that occurs off the job(Rui et al., 2015).

Many researchers argue that on the job training methods are necessary techniques to develop project managers' skills and competencies(Gemünden et al., 2018; Omolo, 2015; S.Vasanthi 
\& Basariya, 2019; Seidle, Fernandez, \& Perry, 2016).and they are best used for skill development(Miri et al., 2014; Sabir et al., 2014).

Matsuo, (2014), stated that about70 per cent of training and learning occurs through on-the-job training methods. And according to(Galport \& Azzam, 2017; Takey \& Carvalho, 2015),it is better for project managers and teams to learn through on the job training to develop competencies and skills. Gemünden, Lehner, \& Kock, (2018), Kum et al., (2014)\& Sharma, (2014)agreed with previous researchers that the on-the job training methods are crucial for project management development and training to provide skills and learn how to work in project environments in a practical way and help to transfer knowledge and skills from one project to other projects inside the organization.

\section{Off-The-Job Methods and Project Performance}

The second class of training methods is off-the job which conducted in separate from the job environment, in this section(Martin et al., 2014; Ramazani \& Jergeas, 2015)investigated the role of lecture as a popular method widely used in project management training mainly for its characteristics it can perform for a wide number of audience, its designing takes lower time.(Calderón \& Ruiz, 2014; Eduardo et al., 2015; Jeong \& Bozkurt, 2014; Lui, Leung, Ng, \& Lee, 2015; Misfeldt, 2015; Telukunta et al., 2014)focused on Games-Based Training as an ideal training tool, which project managers can use and it is useful for project management training.

Damnjanovic, Asce, Rispoli, \& Asce, (2014 ),\& Martin et al., (2014)emphasizes that the case study method creates a simulated environment to think analytically and to understand engineering decision-making process. moreover, sensitivity training and vestibule training are off-the-job training techniques which are to train the project team who deal with machines and tools and respecting others in workplace(Chaubey \& Subramanian, 2014; Singh \& Jain, 2017).

\section{Conclusion}

This paper focusses on the training methods. The researchers used two criteria to compare and analyse and these training methods, the usage of these methods in project management training and their impacts on skills of project team members.

From this paper, we concluded that the project managers and project team members need soft and hard skills to perform their jobs and the training methods and techniques have an impact on skills development and there is a positive relationship between training methods and employees' performance. Hence, an ongoing training and development for improving competencies and skills and updating information and knowledge is a crucial issue. Also, the result of the study reveals that on-the-job training methods are common methods in the project management skills training and they are mostly used in project management training because they are easy to perform, simple, economical, effective and their positive impact on empolyees' performance. In addition, Lecture method as classical technique is still using in project management training to give skills, knowledge, basic concepts and ideas and simulation is a tool for learning by experimentation can improve trainees' skills and allow them to learn from error. And most of the off-the-job training methods are not used in project management training.

\section{References}


Abomeh, O., \& Peace, N. (2015). Effects of Training on Employees' Productivity in Nigeria Insurance Industry. British Journal of Economics, Management \& Trade, 7(3), 227235. https://doi.org/10.9734/BJEMT/2015/15001

Achaliya, R. B., \& Agarwal, P. (2016). Impact of Soft Skills Training Versus Technical Skills Training on Work Efficiency of Professionals - Comparative Analysis. International Journal of Latest Technology in Engineering, Management \& Applied Science, 5(2), 31-33.

Akter, N. (2016). Employee Training and Employee Development Is the Predictors of Employee Performance ; A Study on Garments Manufacturing Sector In Bangladesh ., 18(11), 48-57. https://doi.org/10.9790/487X-1811014857

Balcar, J. (2016). Is it better to invest in hard or soft skills? Economic and Labour Relations Review, 27(4), 453-470. https://doi.org/10.1177/1035304616674613

Berg, M. E., \& Karlsen, J. T. (2016). A study of coaching leadership style practice in projects. Management Research Review, 39(9), 1122-1142.

Bredillet, C., Tywoniak, S., \& Dwivedula, R. (2014). What is a good project manager? An Aristotelian perspective. JInternational Journal of Project Management, 33(2), 254266. https://doi.org/10.1016/j.ijproman.2014.04.001

Brien, E. O., \& Hamburg, I. (2014). Supporting Sustainable Strategies for SMEs through Training , Cooperation and Mentoring, 4(2), 61-69. https://doi.org/10.5539/hes.v4n2p61

Calderón, A., \& Ruiz, M. (2014). Bringing Real-life Practice in Software Project Management Training Through a Simulation-based Serious Game. CSEDU (2), 117-124.

Chaubey, D. S., \& Subramanian, K. R. (2014). Role of Sensitivity Training and its impact on Organization Behavior in a world of cascading Demographic divide . Management, 14(1), 343-356.

Corseuil, C. H., Foguel, M., \& Gonzaga, G. (2019). Apprenticeship as a Stepping Stone to Better Jobs: Evidence from Brazilian Matched Employer-Employee Data. Labour Economics, 57, 177-194. https://doi.org/10.1016/j.labeco.2019.02.002

Damnjanovic, I., Asce, M., Rispoli, J., \& Asce, F. (2014). Case Study Narrative in Teaching Construction Project Management: Earned Value Method Examples. Practice Periodical on Structural Design and Construction, 19(1), 41-49. https://doi.org/10.1061/(ASCE)SC.1943-5576.0000192.

Downey, G., Dalidowicz, M., \& Mason, P. H. (2015). Apprenticeship as method: embodied learning in ethnographic practice. https://doi.org/10.1177/1468794114543400

Dziekoński, K. (2017). Project Managers ' Competencies Model for Construction Industry in Poland. Procedia Engineering, 182, 174-181. https://doi.org/10.1016/j.proeng.2017.03.157

Eduardo, J., Lino, N., Paludo, M. A., Binder, F. V., Reinehr, S., Malucelli, A., \& Informática, P. D. P. (2015). Project Management Game 2D ( PMG-2D ): A Serious Game to Assist Software Project Managers Training. IEEE Frontiers in Education Conference (FIE), $1-8$.

Erbas, I. (2016). Using Case Study Method in Project Management Education as a Tool for Improvement of Project Manager' s Skills. European Journal of Social Sciences Education and Research, 3(1), 121-127.

Erina, I., Ozolina-Ozola, I., \& Gaile-Sarkane, E. (2015). The Importance of Stakeholders in Human Resource Training Projects. Procedia - Social and Behavioral Sciences, 213, 794-800. https://doi.org/10.1016/J.SBSPRO.2015.11.477

Fagerholm, F., Guinea, A. S., Münch, J., \& Borenstein, J. (2014). The role of mentoring and project characteristics for onboarding in open source software projects, 1-10. https://doi.org/10.1145/2652524.2652540 
Falola, H. O., Osibanjo, a O., \& Ojo, S. I. (2014). Effectiveness of Training and Development on Employees ' Performance and Organisation Competitiveness in the Nigerian Banking Industry. Bulletin of the Transilvania University of Brasov Series V: Economic Sciences, 7(56), 161-170. https://doi.org/10.1057/palgrave/ejis/3000424

Galport, N., \& Azzam, T. (2017). Evaluator Training Needs and Competencies: A Gap Analysis. American Journal of Evaluation, 38(1), 80-100. https://doi.org/10.1177/1098214016643183

Gemünden, H. G., Lehner, P., \& Kock, A. (2018). The project-oriented organization and its contribution to innovation. International Journal of Project Management, 36(1), 147160. https://doi.org/10.1016/j.ijproman.2017.07.009

Ibrahim, R., Boerhannoeddin, A., \& Bakare, K. K. (2017). The effect of soft skills and training methodology on employee performance. European Journal of Training and Development. https://doi.org/10.1108/EJTD-08-2016-0066

Indira, M. (2017). Training and development in the organisations : A conceptual framework. International Journal of Humanities and Social Science Research, 3(11), 19-24.

Isabel, M., Aragón, B., Jiménez, D. J., \& Valle, R. S. (2014). Training and performance: The mediating role of organizational learning. BRQ Business Research Quarterly, 17(3), 161-173. https://doi.org/10.1016/j.cede.2013.05.003

Jałocha, B., Krane, H. P., Ekambaram, A., \& Prawelska-Skrzypek, G. (2014). Key Competences of Public Sector Project Managers. Procedia - Social and Behavioral Sciences, 119, 247-256. https://doi.org/10.1016/j.sbspro.2014.03.029

Jena, A., \& Satpathy, S. S. (2017). Importance of Soft Skills in Project Management. International Journal of Scientific Research and Management, 5(07), 6173-6180. https://doi.org/10.18535/ijsr

Jeong, K., \& Bozkurt, I. (2014). Evaluating a Project Management Simulation Training Exercise. Systems $\quad$ Engineering, 26-36. https://doi.org/10.1177/1046878113518481

Kagona, J., Shukla, J., \& Oduor, J. (2015). The effect of employee training on project performance A case of the Girl Child Catch up project of the International Education Exchange. Journal of Marketing and HR (JMHR), 1(1), 33-40.

Khamaksorn, A. (2016). Project Management Knowledge and Skills for the Construction Industry. Nternational Conference on Civil, Architecture and Sustainable Development (CASD-2016) Dec. 1-2, 2016 London(UK) Project.

Khera, S. N., \& Gulati, K. (2015). Training Methods and Tacit Knowledge Sharing: Evidence from IT Organizations. Jindal Journal of Business Research, 4(1-2), 11-26. https://doi.org/10.1177/2278682116649849

Konings, J., \& Vanormelingen, S. (2014). The Impact of Training on Productivity and Wages: Firm-Level Evidence. Review of Economics and Statistics, 97(2), 485-467. https://doi.org/10.1162/REST

Kulkarni, P. (2013). A Literature Review on Training \& Development and Quality of Work Life. International Refereed Research Journal, IV(2), 136-143. https://doi.org/10.3860/ber.v20i2.1909

Kum, F., Cowden, R., \& Karodia, A. (2014). The impact of training and development on employee performance: A case study of ESCON Consulting. SINGAPOREAN JOuRNAl Of BuSINESS EcONOmIcS, ANd Management Studies, 3(3), 72-105.

Lui, R. W. C., Leung, H. K. N., Ng, V. T. Y., \& Lee, P. T. Y. (2015). PMS - A Simulation Game for Interactive Learning of Software Project Management. Transforming Educational Practices with Technology, 104-115. 
Manullang, M. (2017). The Effect of Soft Skills , Competence and Human Relations Skills on Principal Leadership. International Journal of Academic Research in Economics and Management Sciences, 6(4), 14-27. https://doi.org/10.6007/IJAREMS/v6-i4/3413

Martin, B. O., Kolomitro, K., \& Lam, T. C. M. (2014). Training Methods: A Review and Analysis. Human Resource Development Review 2014, 13(1), 11-35. https://doi.org/10.1177/1534484313497947

Matsuo, M. (2014). Instructional skills for on-the-job training and experiential learning: An empirical study of Japanese firms. International Journal of Training and Development, 18(4), 225-240. https://doi.org/10.1111/ijtd.12035

Minniti, L. F. S., Melo Jr, J. S. M., Oliveira, R. D., \& Salles, J. A. A. (2017). The use of case studies as a teaching method in Brazil. Procedia - Social and Behavioral Sciences, 237(June 2016), 373-377. https://doi.org/10.1016/j.sbspro.2017.02.024

Miri, S. A., Mansor, N. N. A., Chasempour, Z., \& Anvari, R. (2014). Staff Organization Training: Designing, Stages, and Methods. Procedia - Social and Behavioral Sciences, 129, 227-235. https://doi.org/10.1016/j.sbspro.2014.03.671

Misfeldt, M. (2015). Scenario based education as a framework for understanding students engagement and learning in a project management simulation game. Electronic Journal of E-Learning, 13(3), 181-191.

Nakanjako, D., Katamba, A., Kaye, D. K., Okello, E., Kamya, M. R., Sewankambo, N., \& Mayanja-kizza, H. (2014). Doctoral training in Uganda : evaluation of mentoring best practices at Makerere university college of health sciences, 1-8.

Nazir, S., Øvergård, K. I., \& Yang, Z. (2015). Towards Effective Training for Process and Maritime Industries. Procedia Manufacturing, 3(Ahfe), 1519-1526. https://doi.org/10.1016/j.promfg.2015.07.409

Omolo, J. (2015). Training and Development on Performance of Small and Medium Enterprises in Kisumu County, Kenya. International Journal of Research in Business Studies and Management, 2(8), 26-31.

Oparanma, A. O., \& Nwaeke, L. I. (2015). Impact of Job Rotation on Organizational Performance, 7(3), 183-187. https://doi.org/10.9734/BJEMT/2015/12051

Oseghale, R. O., Malik, A., Nyuur, R. B., Pereira, V., \& Ellis, F. Y. A. (2018). Drivers of training and talent development: insights from oil and gas MNCs in Nigeria. Human Resource Development International, O0(00), 1-23. https://doi.org/10.1080/13678868.2018.1472479

Pons, D. (2016). Project Management for New Product Development. Project Management Journal, (June), 269-272. https://doi.org/10.1002/pmj

Project Management Institute. (2017). A guide to the project management body of knowledge (PMBOK guide). Project Management Institute. https://doi.org/10.1002/pmj.20125

Radujkovi, M., \& Sjekavica, M. (2017). Project Management Success Factors. Procedia Engineering, 196(June), 607-615. https://doi.org/10.1016/j.proeng.2017.08.048

Raheja, K. (2015). Methods of training and development. Innovative Journal of Business and Management, 4(2), 35-41.

Ramazani, J., \& Jergeas, G. (2015). Project managers and the journey from good to great: The benefits of investment in project management training and education. International Journal of Project Management, 33(1), 41-52. https://doi.org/10.1016/j.ijproman.2014.03.012

Rodriguez, J., \& Walters, K. (2017). The Importance of Training and Development in Employee Performance and Evaluation. International Journal Peer Reviewed Journal Refereed Journal Indexed Journal UGC Approved Journal Impact Factor, 3229(1), 206-212. Retrieved from www.wwjmrd.com 
Rui, L. M., Ismail, S., \& Hussaini, M. (2015). Professional development of project management for contractor in the construction project : a review. Procedia - Social and Behavioral Sciences, 174, 2940-2945. https://doi.org/10.1016/j.sbspro.2015.01.1032

Rupietta, C., \& Backes-Gellner, U. (2018). How firms ' participation in apprenticeship training fosters knowledge diffusion and innovation. Journal of Business Economics, 74(74).

S.Vasanthi, \& Basariya, S. R. (2019). On The Job Training Imlementation And Its Benefits. International Journal of Research and Analytical Reviews (IJRAR), 6(1).

Sabir, R. I., Akhtar, N., Bukhari, farasat ali shah, Nasir, J., \& Ahmed, W. (2014). Impact of Training on Productivity of Employees: A Case Study of Electricity Supply Company in Pakistan. International Review of Management and Business Research, 3(2), 12.

Santos, R. E. S., Fabio, Q. B., Teresa, M., \& De, C. V. C. (2017). Benefits and limitations of project-to-project job rotation in software organizations: A synthesis of evidence. Information and Software Technology, $0, \quad 1-19$. https://doi.org/10.1016/j.infsof.2017.04.006

Savelsbergh, C. M. J. H., Havermans, L. A., \& Storm, P. (2016). Development paths of project managers: What and how do project managers learn from their experiences? International Journal of Project Management, 34(4), 559-569. https://doi.org/10.1016/j.ijproman.2016.02.005

Seidle, B., Fernandez, S., \& Perry, J. L. (2016). Do Leadership Training and Development Make a Difference in the Public Sector? A Panel Study. Public Administration Review, 76(4), 603-613. https://doi.org/10.1111/puar.12531.Do

Sharma, H. (2014). Importance and performance of managerial training in Indian companies an empirical study. Journal of Management Development, 33(2), 75-89. https://doi.org/10.1108/JMD-11-2013-0144

Singh, C., \& Jain, V. K. (2017). Effect of Training on Organizational Performance. International Journal of Application or Innovation in Engineering \& Management (IJAIEM), 6(7), 53-59.

Smits, S. J., Bowden, D., Falconer, J. A., \& Strasser, D. C. (2014). An evaluation of a leadership development coaching and mentoring programme. Leadership in Health Services, 27(4), 229-315. https://doi.org/10.1108/LHS-02-2014-0010

Takey, S. M., \& Carvalho, M. M. de. (2015). Competency mapping in project management: An action research study in an engineering company. International Journal of Project Management, 33(4), 784-796. https://doi.org/10.1016/j.ijproman.2014.10.013

Tamm, M. (2018). Training and Changes in Job Tasks Training and Changes in Job Tasks. Economics of Education Review, 67, 137-147.

Telukunta, S., Kota, S. K., Potti, S., Shashank, H., \& Reddy, T. (2014). StrateJect: An Interactive Game for Project Management Experiential Learning. PMP Conference, PMI Bangalore Chapter.

Thomas, M., Partridge, T., Pidgeon, N., Herr, B., Demski, C., \& Hasell, A. (2018). Energy Research \& Social Science Using role play to explore energy perceptions in the United States and United Kingdom. Energy Research \& Social Science, 45, 363-373. https://doi.org/10.1016/j.erss.2018.06.026

Thompson, S., \& Cox, E. (2017). How Coaching is Used and Understood. Project Management Journal, 48(5), 64-77. https://doi.org/10.1177/875697281704800505

Vaughan, K. (2017). The role of apprenticeship in the cultivation of soft skills and dispositions. Journal of Vocational Education \& Training, 69(4), 540-557. https://doi.org/10.1080/13636820.2017.1326516

Vinesh. (2014). Role of Training \& Development in an Organizational Development. International Journal of Management and International Business Studies, 4(2), 213220. 
Whetzel, D. L., Rotenberry, P. F., \& Mcdaniel, M. A. (2014). In-basket Validity : A systematic review. International Journal of Selection and Assessment, 22(1).

Zhang, J., Yu, P. S., \& Lv, Y. (2017). Enterprise Employee Training via Project Team Formation. Proceedings of the Tenth ACM International Conference on Web Search and Data Mining - WSDM '17, (1), 3-12. https://doi.org/10.1145/3018661.3018682 